\title{
A Látrányi Puszta Természetvédelmi Terület levélbogár faunája (Coleoptera: Chrysomelidae)
}

\author{
ROZNER ISTVÁN
}

H-1116 Budapest, Tétényi-út 129., Hungary

Rozner 1:: The leaf beetle fauna of the Látrányi Puszta Nature Conservation Area (Coleoptera: Chrysomelidae)

Abstract: Abstract: At the moment 11 subfamilies, 44 genera and 144 species are known to occur in Látrányi Puszta Nature Conservation Area (Somogy County, Hungary). This paper is based on the collections carried out between 1998 and 2002.

Key words: Coleoptera, Chrysomelidae, faunistical evaluation

\section{Bevezetés}

A Somogy megyei Látrány község melletti Látrányi Puszta Természetvédelmi Területet 1992-ben alapították 222,3 hektáron. A védett terület Külsö-Somogyra jellemző meszes talajú homokpuszta, nagyrészt gyeppel boritott hajdani legelőkkel, kaszálókkal és nedves láprétekkel. Védetté nyilvánítását a területen nagy tömegben előforduló ritka védett növények (pl. kosbor-félék, árvalányhaj, gyapjúsás stb.) indokolták. Rovartani szempontból a terület teljesen feltáratlan volt, rovargyüjtési adatok sem magán, sem közgyüjteményekben nem voltak találhatók.

A Látrányi Puszta Természetvédelmi Területen a rovartani kutatások, a Somogy Megyei Múzeum Természettudományi Osztálya vezetőjének, Ábrahám Leventének szervezésében kezdődött 1998-ban. A 2002-ig tartó, öt éven át folyó kutatások során számos, Somogy megyében eddig nem gyüjtött vagy még nem publikált levélbogár fajt sikerült kimutatni.

\section{Anyag és módszer}

A közölt adatok a Látrányi Puszta TT. kutatására szervezett kutatócsoport gyüjtéseiből származnak. A levélbogarakat gyüjtők névsorát lásd alább, a névrövidítéseknél. A gyüjtések kiterjedtek a Látrányi pusztai legelőkre (Kolláti-, Birkás- és Nyíres-legelő) és a védett terület keleti határát képező Tetves-patak mellékére. A természetvédelmi területen belül hat, kisebb-nagyobb mintaterület lett kijelölve, melyek jellegzetes élőhelyeket reprezentálnak. Ezeket az lelöhelyek jegyzékében és a fajlistában külön feltüntettem.

A levélbogarak gyüjtése hagyományos módszerek alkalmazásával történt. Csekély mértékben alkalmaztuk az egyelést, hiszen a levélbogarak kis méretéből következően, ez a módszer csak kevés faj gyüjtésénél volt eredményes. Annál eredményesebb volt a zacskós fühálózás, ami azt jelentette, hogy a hálózott anyagot egy müanyag zacskóban összegyüjtve öltük le, ezáltal nem csak a bogarak, hanem egyéb rovarok is begyüjtésre 
kerültek. Válogatás után ezek a rovarrendek, családok a feldolgozó szakemberekhez kerültek. Ugyancsak eredményes gyüjtési módszer volt a kopogtatás a fákról, bokrokról. Alkalmaztuk még a talajcsapdázást, bár a csapdákba levélbogarak csak ritkán kerültek. A fákra függesztett illatcsapdák sem hoztak jelentős levélbogár-anyagot.

\section{Eredmények}

A fajlistában szereplő taxonok rendszerét ROzNER (1996) közleménye alapján tárgyalom, mivel ez kiegészíti az általában Magyarországon használt faunafüzetet (KASZAB 1962), jóllehet azóta már újabb rendszertani módosítások is ismeretesek.

A fajok felsorolásánál a következő sorrendet alkalmaztam: 1. Fajnév. 2. Lelöhely (rövidítve). 3. Gyüjtés ideje (év, hó, nap). 4. Gyüjtési módszer (ha van adatszolgáltatás, rövidítve). 5. Gyüjtő neve (rövidítve) 6. Állatföldrajzi besorolás RozNER (1992) alapján. 7. Magyarországi és Somogy megyei elterjedésére vonatkozó adatok. 8. Tápnövények.

A lelőhelyek rövidítései:

1. Lát - $\quad$ A Látrányi puszta TT közelebbi gyüjtőhely megjelölés nélkül.

2. Lát 1 - Kijelölt mintaterület a Kolláti-legelön. Zsombékos láprét.

3. Lát2 - Kijelölt mintaterület a Birkás-legelön. Égeres szegélyén nedves rét.

4. Lát3 - Kijelölt mintaterület a Birkás legelőn. Homokdomb árvalányhajas ho mokpuszta gyeppel.

5. Lát4 - Kijelölt mintaterület a Birkás-legelőn. Nedves kaszálórét.

6. Lát5 - Kijelölt mintaterület a Birkás legelőn. Cseres tölgyes gyepszegéllyel.

7. Lát6 - Kijelölt mintaterület a Birkás legelőn. Gyapjúsásos láprét.

8. Kol - Látrányi puszta, Kolláti-legelő

9. Bir - Látrányi puszta, Birkás-legelő

10. Nyir - Látrányi puszta, Nyíres-legelö

11. Tet - Látrányi puszta, Tetves-patak melléke

A gyüjtők neveinek rövidítései:

ÁL - Ábrahám Levente

$\mathrm{KE}$ - Kondorosy Elöd

MO - Merkl Ottó

PA - Podlussány Attila

RGY - Rozner György

RI - Rozner István

SZD - Szalóki Dezső

\section{Chrysomelidae}

Donaciinae Kirby, 1837

Donacia (Donacia) simplex Fabricius, 1775 . Tet.: 2002. IV. 26., fh, RI - Palcarktikus faj. Magyarországon elterjedt és közönsćges. Somogy megyéböl ez az clső gyüjtćsi adat. Tn.: Glyceria, Carex és Sparganium fajok.

Plateumaris consimilis (Schrank, 1781) - Lát.: 2000. IV. 29., ÁL - Euroszibćriai faj. Magyarországon közönsćges. Elsö Somogy megyci gyüjtćsi adat. Tn.: Caltha palustris ćs a Carex fajok.

\author{
Egyéb rövidítések: \\ $\mathrm{Tn}=$ tápnövény \\ egy = egyelés \\ fh = fühálózás \\ kop $=$ kopogtatás \\ tcs = talajcsapda
}

Orsodacninae Thomson, 1859

Orsodacne lineola (Panzcr, 1795) - Lát5.: 2002. V. 4., fh, MO; Kol.: 2000. IV. 29., fh, RI Holomediterrán faj, hazánkban a síkságon ćs a hegyvidéken clterjedt és gyakori, föként az crdőszegélyek cserjéin.

\section{Criocerinae Latreille, 1807}

Lema (Lema) cyanella (Linnacus, 1758) - Lát.: 2001. IV. 24., fh, RGY; Bir.: 2002. IV. 26., fh, PA. Eurázsiai faj. Magyarországon elterjedt és nem ritka. Tn.: Cirsium arvense. 
Oulema (Haspidolema) gallaeciana (Heyden, 1870) - Tet.: 2001. IV. 29., fh, RGY; 2002. IV. 26., fh, PA. - Euroszibériai faj. Magyarországon a vizenyős helyeken mindenfelé elterjedt és közönséges. Tn.: Triticum aestivum és a Cirsium fajok.

Oulema melanopus (Linnacus, 1758) - Lát.: 2001. IV. 12., RGY; Lát1.: 2001. VII. 10., KE, 2002. IV. 26, fh, RI; Lát4.: 2002. IV. 26., fh, RI; Lát5.: 2002., IV. 26., fh, RI; Lát6.: 2001. VII. 3., KE; Kol.: 2001. VI. 3., RI, 2001. VII. 10., KE, 2001. X. 5., PA; Bir.: 1999. III. 31., fh, RGY, 2001. IV. 26., fh, RI, 2001. X. 5., PA et RI, 2002. IV. 26., fh, PA; Nyir.: 2002. IV. 26., fh, RI; Tet.: 2002. IV. 26., fh, Rl; Bókhegy, Duda-tetö, 1998. III. 30-31, RGY. - Nyugatpalearktikus faj, amely a pázsitfü-félćken mindenütt clőfordul, nagyon közönsćges, helyenként kártcvőként jelentkezik.

Crioceris duodecimpunctata (Linnacus, 1758) Lát.: 1998. VI. 22., egy, RGY, 1999. V. 12., egy, RGY; Bir.: 1999. V. 22., egy, RGY, 2000. VI. 4., fh, RI. - Pontusi clterjedésü faj, az Asparagus fajokon található és gyakori.

Crioceris quatuordecimpunctata (Scopoli, 1763) - Lát.: 1999. V. 12., 2001. IV. 24., egy, RGY, 2001. VII. 31., fh, SZD, 2002. VI. 30., fh, MO; Kol.: 2001. X. 5., PA; Bir.: 1999. V. 22., 2001. VII. 19., egy, RGY. - Euroszibériai-mongol elterjedésü faj. Tn.: Asparagus officinalis. Gyakori faj hazánkban.

Crioceris quinquepunctata (Scopoli, 1763) Lát.: 1999. V. 12., 2001. IV. 24., 2001. VII. 3., cgy, RGY, 2001. VII. 31, fh, SZD; Lát5.: 2001. VII. 5., fh, MO; Bir.: 1999. V. 22., egy, 2000. IV. 29., 2001. VIl. 19., RGY; Kol.: 2001. IV. 26., fh, RI. - Pontusi elterjedésü faj. Faunaterületünkön elterjedt és gyakori. Tn.: Asparagus officinalis.

Lilioceris merdigera (Linnacus, 1758) - Kol.: 2002. IV. 2., RGY. - Euroszibćriai clterjedésü faj. Faunaterületünkön sokfelé clöfordul és gyakori. Tn.: Convallaria majalis, és a Lilium, Polygonatum, Allium, Muscari fajok.

\section{Clytrinae Kirby, 1837}

Labidostomis tridentata (Linnacus, 1758) Lát2.: 2001. VII. 10., KE. - Euroszibériai faj. Magyarországon a hegy- és dombvidéken elterjedt, de nem gyakori. Első Somogy megyei gyüjtési adat. Tn.: tölgy és mogyoró, de clöfordul nyiren és füzön is.

Labidostomis longimana (Linnaeus, 1761) - Lát.: 1998. VI. 22., 2001. VI. 16., fh, RGY, 1998.VI. 28., fh, RI, 2002. VI. 30., fh, MO; Lát1.: 2001. VII. 5., fh, MO, 2001. VII. 10., KE; Lát2.: 2001. VII. 10., KE; Lát6.: 2001. VII. 3., KE; Bir.: 2001. VI. 26., fh, RI, 2001. VIl. 19., RGY; Kol.: 2000. VI. 3., fh, RI, 2000. VI. 4., RGY. - Euroszibćriai faj. Magyarországon mindenfelć közönsćgcs. Tn.: pázsitfü-fćlćk.

Clytra laeviuscula Ratzeburg, 1837 - Lát.: 1998. VI. 22., fh, RGY, 1998. VI. 27., egy, RGY; Bir.: 1999. VI. 2., cgy, RGY, 2000. VI. 4., fh, RI; Kol.: 2000. VI.
3., kop, RI. - Eurázsiai faj. Magyarországon a füz- és nyár-féléken nagyon közönséges.

Smaragdina salicina (Scopoli, 1763) - Lát.: 1998. VI. 22., fh, RGY, 1998. VI. 27., egy, fh, RGY, 2001. V. 13., SZD; Lát5.: 2002. V. 4., fh, MO; Kol.: 2000. V. 13., KE et RGY; Bir.: 2000. V. 13., RGY, 2002. IV. 26., fh, PA; Nyir.: 2002. IV. 26., fh, RI; Tet.: 2001. IV. 25., RGY. - Eurázsiai faj. Magyarországon a füzféléken és galagonyán közönséges.

Smaragdina flavicollis (Charpentier, 1825) Bir.: 2001. VI. 14., RGY. - Atlanto-mediterrán faj. Magyarországon föleg a hegyvidékeken elterjedt ritka faj. Tn.: éger.

Smaragdina aurita (Linnacus, 1767) - Lát.: 1998. VI. 22., fh, RGY. - Eurázsiai elterjedésü faj. Magyarországon a hegy- és dombvidék lakója. Ncm ritka. Tn.: mogyoró-, füz- és nyírfélék.

Smaragdina xanthaspis (Germar, 1824) - Lát.: 1998. VI. 22., fh, RGY - Kclet-mediterrán faj. Magyarországon a hegy és dombvidéken a fák lombjában közönséges.

Smaragdina affinis (Illiger, 1794) - Lát.: 2001. IV. 24., RGY; Lát5.: 2002. V. 4., fh, MO; Kol:: 2000. IV. 29., RI; Bir.: 2000. V. 13., RGY, 2001. IV. 26., fh, RI. - Euro-afrikai faj. Magyarországon clterjedt és gyakori a lomblevelü fákon, de a fészkes virágzatú növénycken is. Somogy megyében ezek az clső gyüjtési adatok.

Coptocephala unifasciata (Scopoli, 1763) - Lát.: 1998. VIII. 20., fh, RGY, 1999. VII. 25, fh, RI, 2002. VI. 30., fh, MO; Lát1 : 2001 . VII. 5., fh, MO; Bir.: 1999. Vl. 12., 2001. VII. 19., fh, RGY; Kol.: 2001. X. 5., fh, PA et RI. - Kelct-mediterrán faj. Magyarországon általánosan clterjedt ćs nagyon gyakori. Tn.: Pastinaca sativa ćs Daucus carota.

\section{Cryptocephalinae Gyllenhal, 1813}

Pachybrachis sinuatus Mulsant et Rey, 1859 . Lát.: 1998. VI. 22., 2001. V1. 26., fh, RGY; Lát1.: 2001. VII. 5., fh, MO. - Közćp-európai hegyvidéki faj. Nem gyakori. Tn.: Myricaria germanica

Cryptocephalus (Homalopus) coryli (Linnaeus, 1758) - Lát5.: 2002. V. 4., fh, MO; Bir.: 2000. V. 13., RGY, 2002. IV. 26., fh, PA. - Euroszibćriai faj. Magyarországon a tápnövényén, a mogyorón, mindenfelé megtalálható. Somogy megyében ez az első gyüjtési adat.

Cryptocephalus (Burlinius) bilineatus (Linnaeus, 1767) - Lát.: 1998. VI. 22., fh, RGY, 1998. VI. 27., fh, RGY, 1998. VI. 28, fh, RI, 2001. VII. 31, fh, SZD, 2002. VI. 30., fh, MO; Lát3.: 2001. VII. 10., KE; Lát5.: 2001. VII. 5., fh, MO; Bir.: 1999. VII. 12., fh, RGY, 2001. VI. 26., fh, RI; Kol.: 2000. VI. 3, fh, RI. - Eurázsiai elterjedésü faj. Magyarországon clterjedt és nagyon gyakori.

Cryptocephalus (Burlinius) chrysopus Gmclin, 1790 - Lát4.: 2002. IV. 26., fh, RI; Bir.: 2000. V. 13., 2001. IV. 25., 2001. VI. 14., RGY, 2002. IV. 26., fh, 
PA. - Pontusi faj. Magyarországon a hegy és dombvidéken közönséges. Somogy megyében ez az első gyüjtési adat.

Cryptocephalus (Burlinius) ocellatus Drapiez, 1819 - Lát.: 1998. VI. 22., fh, RGY; Lát1 .: 2001. VII. 5., fh, MO; Lát2.: 2001. VlI. 10., KE; Kol.: 1999. VII. 12., fh, RGY, 2000. V. 13., RGY, 2000. VI. 3., fh, RI, 2000. VI. 4., RGY; Bir.: 1999. VII. 12., fh, 2001. VI. 14., RGY. - Ponto-mediterrán faj. Magyarországon elterjedt. A vizenyős helyeken közönséges. Tn.: a füz, nyír, nyár fafajok és a mogyoró.

Cryptocephalus (Burlinius) exiguus Schneider, 1792 - Lát.: 1998. VI. 22., fh, RGY; Kol.: 2000. V. 13., RGY. - Euroszibćriai faj. Magyarországon a lápos helyeken található, nem gyakori. Somogy megyében czck az clső gyüjtési adatai. Tn.: a füz és nyír fajok.

Cryptocephalus (Burlinius) connexus Olivier, 1808 - Lát.: 1999. VII. 25., fh, RI. - Pontusi faj. Magyarországon a nedves réteken közönséges.

Cryptocephalus (Burlinius) fulvus (Goeze, 1777) - Lát.: 1998. VIIl. 20., fh, RGY; Kol.: 2001. X. 5., fh, Rl. - Euroszibćriai clterjedésü faj. Magyarországon a száraz rétcken, pusztafüves lejtökön clterjedt, nem ritka.

Cryptocephalus (Burlinius) macellus Suffrian, 1860 - Lát.: 1999. VII. 25., fh, RI. - Közép- és Délcurópai faj. Magyarországon szórványos clöfordulású. Első Somogy megyei gyüjtési adat. Tn.: a tölgy és a kökény.

Cryptocephalus (Burlinius) populi Suffrian, 1848 - Lát.: 2001. VI. 26., 2001. VII. 19., fh, RGY. Nyugat- ćs Közép-európai faj. Magyarországon clterjedt és nem ritka. Első adatok Somogy megyéböl. Tn.: Populus fajok.

Cryptocephalus (Burlinius) pusillus Fabricius, 1776 - Bir.: 2001. VI. 14., fh, RGY. - Európai faj. Magyarországon cltcrjedt ćs gyakori. Tn.: tölgy, mogyoró, füz, nyár, nyír ćs ćger.

Cryptocephalus (Cryptocephalus) sexpunctatus (Linnaeus, 1758) - Bir.: 2000. IV. 29, 2001. IV. 25., RGY, 2000. V. 13., KE - Eurázsiai faj. Magyarországon clterjedt ćs nem ritka. Elsö Somogy megyei gyüjtćsi adatok. Tn.: a füz, tölgy, mogyoró, nyír, galagonya és kőris.

Cryptocephalus (Cryptocephalus) bipunctatus (Linnacus, 1758) - Lát.: 1998. Vl. 22., fh, RGY, 2000. V. 13., KE; Bir: 1999. VII. 12., fh, RGY. Euroszibćriai faj. Magyarországon mindenütt nagyon közönséges. Tn.: tölgy és más fák és cserjék.

Cryptocephalus (Cryptocephalus) sericeus sericeus (Linnacus, 1758) - Lát.: 1998. Vl. 22.,1998. VIII. 22., fh, RGY, 1998. VI. 28., fh, 1999. VII. 25., fh, RI, 2001. VII. 31, fh, SZD; Lát1.: 2001. VII. 5., fh, MO; Bir.: 2001. VI. 26., fh, RI. - Ponto-mediterrán faj. Magyarországon mindenfelé közönsćges. Tn.: Compositae.

Cryptocephalus (Cryptocephalus) hypochaeridis hypochaeridis (Linnacus, 1758) - Lát.: 1998. VI. 22. fh, 2001. VI. 16., 2001. VII. 3., RGY, 2001. VII. 10., KE, 2002. VI. 30., fh, MO; Lát2.: 2001. VII. 10, KE; Kol.: 2000. VI. 3., fh, RI, 2000. VI. 4., RGY; Bir.: 2001. VI. 26., 2001. VII. 19., fh, Rl. - A nevezćk faj euroszibćriai clterjedésü ćs Somogy megyében nagyon gyakori. Tn.: Compositae.

Cryptocephalus (Cryptocephalus) violaceus Laicharting, 1781 - Lát.: 2000. V. 13., KE, 2001. V. 13. fh, RI et SZD; Bir.: 2000. V. 13., RGY. - Euroanatóliai cltcrjedésü faj. Magyarországon közönséges. Tn.: füz, éger, galagonya és különfćle virágok.

Cryptocephalus (Cryptocephalus) gridellii Burlini, 1956 - Lát.: 1998. VI. 22., fh, RGY. Adriato-mediterrán eltcrjedésü faj. Nálunk nagyon ritka. Első adat Somogy megyćből. Tn.: ismeretlen.

Cryptocephalus (Cryptocephalus) nitidus (Linnaeus, 1758) - Bir.: 2000. V. 13., 2001. VI. 14., fh, RGY. - Euroszibériai clterjedésủ faj. Magyarországon a hegy- és dombvidéken gyakori. Tn.: mogyoró, füz, nyír és tölgy.

Cryptocephalus (Cryptocephalus) janthinus Germar, 1824 - Lát.: 1998. VI. 28., fh, RI; Lát4.: 2001. VII. 3., KE; Bir.: 2001 VII.19., fh, RGY. Euroszibériai faj. Magyarországon a vizcnyős hclycken elterjedt, de nem gyakori. Tn.: Lysimachia vulgaris, de clöfordul a nyíren ćs a nádon is.

Cryptocephalus (Cryptocephalus) parvulus $\mathrm{O}$. F. Müller, 1776 - Bir.: 2000. V. 13., RGY. Euroszibériai elterjedésü faj. Hazánkban a vizenyős helyeken élö ritka faj. Első gyüjtési adat Somogy megyéböl. TN.: nyir, füz, tölgy és galagonya.

Cryptocephalus (Cryptocephalus) moraei (Linnaeus, 1758) - Lát.: 1998. VI. 22., RGY, 1998. VI. 28, fh, RI, 2002. VI. 30., fh, MO; Lát1.: 2000. VII. 10., KE; Lát2.: 2000. Vll. 10., KE; Lát6.: 2001. VII. 3., KE; Kol.: 2000. IV. 29., fh, 2000. VI. 3., fh, RI. - Euroszibériai faj. Magyarországon általánosan cltcrjedt és nagyon közönsćges. Tn.: a Hypericum perforatum és más Hypericum fajok, valamint a Sarothamnus scoparius.

Cryptocephalus (Cryptocephalus) octacosmus Bedel, 1891 - Lát.: 1998. VI. 28., fh, RI; Lát3.: 2001. VII. 10., KE; Lát4.: 2001. VII. 3., KE; Lát6.: 2001. VII. 3., KE. - Euroszibćriai faj. Magyarországon a vizenyős helycken elterjedt és közönsćges.

Cryptocephalus (Cryptocephalus) flavipes Fabricius, 1781 - Lát.: 1998. VI. 22., 2001. VI. 16., fh, RGY, 2000. V. 13., 2001. VII. 10., KE, 2001. V. 13., SZD; Lát1.: 2002. IV. 26., fh, RI; Lát5.: 2001. VII. 5., fh, MO; Kol.: 2000. IV. 29., 2000. VI. 3., fh, RI, 2000. V. 13., RGY; Bir.: 1999. VII. 12., 2000. V. 13., fh, RGY. - Euroszibériai faj. Magyarországon általánosan elterjedt és nagyon közönsćges. Tn.: füz, éger, nyár, nyír, mogyoró, galagonya, és tölgy fajok.

\section{Eumolpinae Thomson, 1859}

Pachnephorus villosus (Duftschmid, 1825) Lát4.: 2002. IV. 26., fh, RI; Bir.: 2000. IV. 29., RGY, 2001. X. 5., fh, RGY et RI, 2002. IV. 26., fh, PA; Tet.: 
2001. IV. 25., RGY. - Pontomediterrán faj. Magyarországon a hegy- és dombvidéken elterjedt és közönséges. Somogy megyéböl ezek az első gyüjtési adatok.

\section{Chrysomelinae Latreille, 1802}

Chrysolina (Euchrysolina) graminis (Linnacus, 1758) - Bir.: 2002. IV. 26., fh, PA. - Észak- és Középcurópai faj. Magyarországon a vizenyős helyeken elterjedt és gyakori. Tn.: Chrysanthemum vulgare.

Chrysolina (Menthastriella) herbacea (Duftschmid, 1825) - Lát1.: 2001. VII. 10., KE; Bir.: 1999. VII. 12., fh, 2000. V. 13., RGY, 2001. IV. 26., fh, RI; Kol.: 2000. V. 13., RGY. - Pontomediterrán faj. Magyarországon a vizes élőhelyeken elterjedt. Tn.: Mentha fajok.

Chrysolina (Erythrochrysa) polita (Linnaeus, 1758) - Lát.: 1998. V. 15., fh, 1998. VI. 22., fh, RGY; Bir.: 2001. X. 5., PA. - Palearktikus faj. Magyarországon a vizes élöhelyeken nagyon közönséges.Tn.: Mentha aquatica, Nepeta cataria, Glechoma hederacea, Salvia pratensis, a Melissa és Origanum fajok.

Chrysolina (Chrysolina) staphylaea (Linnaeus, 1758) - Kol.: 2001. III. 10., RGY, 2001. IV. 12, fh, SZD; Bir.: 2001. X. 5., PA et Rl. - Nyugat-palearktikus faj. Magyarországon elterjedt és a vizes élöhelyeken közönsćges. Tn.: Mentha, Melissa és Ocimum fajok.

Chrysolina (Minckia) chalcites (Germar, 1824) Kol.: 2001. X. 5., fh, RI. - Pontusi elterjedésü faj. Magyarországon clterjedt és nem ritka a homokos talajokon. Somogy megyében cz az első gyüjtési adat.

Chrysolina (Colaphosoma) sturmi (Westhoff, 1882) - Lát5.: 2002. V. 4., fh, MO - Euroszibériai faj. Magyarországon a száraz, füves helyeken gyakori. Tn.: Glechoma hederacea és a Galium fajok.

Chrysolina (Stichoptera) rossia (llliger, 1802) Kol.: 2001. X. 5., egy, RI. - Adriato-mediterrán faj. Magyarországon az Alföldön és a Dunántúlon elterjedt és gyakori. Somogy megyében ez az első gyüjtćsi adat.

Chrysolina (Sphaeromela) varians (Schaller, 1783) - Lát.: 1998. V1. 22., fh, RGY; Kol.: 2000. IV. 29., fh, RI. - Nyugat-palcarktikus faj. Magyarországon föként a hegyvidćkeken gyakori. Tn.: Hypericum fajok.

Chrysolina (Craspeda) limbata limbata (Fabricius, 1775) - Lát.: 2001. IV. 12., fh, SZD; Kol.: 1999. IX. 7., cgy, RGY. - Euroszibériai faj. Magyarországon elterjedt és nem ritka. Tn.: Plantago fajok.

Chrysolina (Fastuolina) fastuosa (Scopoli, 1763) - Bir.: 2000. IV. 29., RGY, 2001. IV. 26., fh, 2001. Vl. 26., fh, RI; Kol.: 2001. IV. 26., th, 2001. X. 5., fh, RI, 2002. IV. 26., fh, PA; Nyir.: 2002. IV. 26., $\mathrm{fh}, \mathrm{RI}$. - Eurázsiai faj. Magyarországon általánosan clterjedt és nagyon közönséges. Tn.: Galeopsis, Lamium, ćs Urtica fajok.

Gastrophysa polygoni (Linnacus, 1758) - Lát.: 1999. VII. 25., 2001. IV. 18., fh, RI, 2001. IV. 24., RGY; Lát1.: 2002. IV. 26., fh, Rl; Bir.: 1999. IV. 14., fh, RGY, 2001. IV. 26., fh, RI, 2002. IV. 26., fh, PA; Kol.: 2000. VI. 3., RI. - Holarktikus faj. Magyarországon mindenütt nagyon közönséges. Tn.: Polygonum aviculare, Polygonum convolvulus, Fagopyrum vulgare és a Rumex fajok.

Gastrophysa viridula (De Geer, 1775) - Lát4.: 2002. IV. 26., fh, RI; Bir.: 2001. X. 5., fh, RI, 2002. IV. 26., fh, PA. - Holarktikus faj. Magyarországon elterjedt és közönséges. Tn.: Rumex és Polygonum fajok.

Phaedon cochleariae (Fabricius, 1792) - Lát.: 1998. IV. 24., fh, RGY; Bir.: 2000. IV. 20., RGY Euro-anatoliai faj. Magyarországon általánosan elterjedt és gyakori a vizenyős helyeken. Tn.: Nasturtium officinale, Rorippa amphibia, Veronica beccabunga és Armoracia rusticana

Hydrothassa glabra (Herbst, 1783) - Lát5.: 2002. V. 4., fh, MO - Euroszibériai faj. Magyarországon a vizenyős helyeken gyakori. Somogy megyéböl ez az elsö adat. Tn.: Ranunculus félék.

Hydrothassa marginella (Linnaeus, 1758) - Bir.: 2001. IV. 26., fh, RI, 2002. IV. 26, fh, PA; Tet.: 2001. IV. 25., RGY. - Euroszibériai faj. Magyarországon a vizes élöhelyeken országszerte előfordul és nem ritka. TN.: Caltha palustris és a Ranunculus félék.

Prasocuris junci (Brahm, 1790) - Lát.: 1998. IV. 24., RGY; Kol.: 2000. IV. 11., RGY; Tet.: 2002, IV. 26., fh, RI. - Kelet-palearktikus faj. Magyarországon a vizenyös területeken mindenütt elterjedt és gyakori. Somogy megyéből ezek az első gyüjtési adatok. Tn.:Veronica beccabunga és a Anagallis aquatica.

Plagiodera versicolora (Laicharting, 1781) Bir.: 2000. IV. 29., RGY. - Holarktikus faj. Magyarországon a vizenyős helyeken általánosan elterjedt és közönséges. Tn.: a füz és nyár fafajok.

Linaeidea (Linaeidea) aenea (Linnaeus, 1758) Lát.: 1998. IV. 24., egy, 1998. V. 15., fh, RGY; Lát5.: 2001. IV. 26., kop, RI; Bir.: 2001. IV. 14., RGY. Eurázsiai faj. Magyarországon a hegy és dombvidéken gyakori. Tn.: Alnus fajok.

Chrysomela (Chrysomela) populi Linnacus, 1758 - Lát.: 1998. VI. 22., 2001. VII. 31., fh, RGY, 1998. VI. 28., egy, RI; Bir.: 2000. V. 13., 2001. IV. 25., RGY - Palearktikus elterjedésü faj. Magyarországon mindenütt nagyon közönséges. Tn.: füz és nyár fafajok.

Chrysomela (Chrysomela) saliceti (Weise, 1884) - Lát.: 1998. IV. 24., cgy, RGY. - Euroszibériai faj. Magyarországon szórványosan clöfordul, nem ritka. Tn.: füzck.

Gonioctena (Spartoxena) fornicata (Brüggemann, 1873) - Lát.: 2001. IV. 24., RGY; Bir.: 2000. IV. 29., 2000. V. 13., RGY. - Pontusi faj. Magyarországon közönséges lucerna kártevő.

Phratora (Chaeroceta) vulgatissima (Linnaeus, 1758) - Lát.: 1998. IV. 24., fh, RGY; Kol.: 1999. VII. 12., cgy, RGY. - Holarktikus elterjedésü faj. Magyarországon szórványosan található, az előfordulási helyein gyakori. Tn.: Salix fajok. 
Phratora (Phratora) vitellinae (Linnaeus, 1758) - Bir.: 2000. V. 13., RGY. - Holarktikus faj. Magyarországon clterjedt és közönséges. Tn.: füz és nyár fafajok.

\section{Galerucinae Latreille, 1802}

Galerucella (Neogalerucella) calmariensis (Linnacus, 1767) - Lát.: 1998. VI. 22., fh, RGY; Lát4.: 2001. VII. 3., KE; Bir.: 2000. V. 13., RGY. Palcarktikus faj. Magyarországon a vizenyős helyeken gyakori. Tn.: Lythrum salicaria.

Lochmaea crataegi (Forster, 1771) - Lát.: 1998. IV. 24., 2001. IV. 24., kop, RGY; Lát5.: 2002. V. 4., fh, MO; Kol.: 1999. VIl. 12., kop, RGY; Bir.: 2000. IV. 20., kop, RGY, 2000. IV. 29., 2001. IV. 26., kop, PA ct RI. - Nyugat-palcarktikus faj. Magyarországon clterjedt ćs gyakori. Tn.:Crataegus fajok.

Galeruca (Haptoscelis) melanocephala (Ponza, 1805) - Lát.: 2001. IV. 12., RGY. - Pontusi faj. Magyarországon clterjedt ćs nem ritka. Tn.: Rumex és Polygonum fajok.

Galenica (Galeruca) tanaceti (Linnaeus, 1758) Lát5.: 2001. VIl. 5., fh, MO; Kol.: 2001. X. 5., egy, RGY; 2001. VI. 14., RGY; Bir.: 2000. V. 13., 2000. VI. 4., egy, RGY, 2001. VI. 26., 2001. X. 5., egy, RI. - Holarktikus faj. Magyarországon mindenütt közönsćges. Tn.: Achillea millefolium, Chrysanthemum, Taraxacum, Cirsium, Stellaria, ćs Cardamine fajok.

Galenica (Galeruca) pomonae (Scopoli, 1763) Lát.: 1998. VI. 28., egy, RI, 2002. VI. 30., fh, MO; Lát1.: 2001. VIl. 5., fh, MO; Kol.: 2001. X. 5. cgy, RGY et RI; Bir.: 2001. VI. 26., 2001. X. 5., egy, RI. - Holarktikus faj. Magyarországon eltcrjedt és közönsćges. TN: Centaurea jacea, Knautia arvensis, Cirsizm palustre, Achillea, ćs Leontodon fajok.

Galeruca (Galeruca) dahli (Joannis, 1865) Lát:: 1998. VI. 22., fh, 1998. VI. 27., RGY; Bir.: 2001. X. 5., RGY. - Pontomeditcrrán elterjedésü faj. Magyarországon sokfclé clőfordul, de ritka. Somogy megyćbỏl ezek az clső gyüjtési adatok. Tn.: Serratula tinctoria.

Luperus xanthopoda (Schrank, 1781) - Bir.: 2001. VI. 14., RGY. - Turano-mediterrán elterjedćsü faj. Magyarországon elterjedt és közönséges. Lombcrdökben, crdőszegélyeken, különféle cserjéken, de legfơképpen szilféléken található.

Luperus longicornis (Fabricius, 1781) - Lát.: 1998. VI. 22., fh, RGY; Bir.: 1999. V. 22 - VI. 24., tcs, RGY, - Eurázsiai faj. Magyarországon ritka. Első Somogy megyci adat. Tn.: Salix, Betula, Alnus fajok.

\section{Alticinae Kutschera, 1859}

Phyllotreta vittula (Redtenbacher, 1849) - Lát.: 2001. IV. 29., fh, SZD, 2001. VI. 26., fh, RGY, 2001. VII. 10., KE; Kol.: 2001. IV. 25., fh, RGY, 2001. IV. 26., fh, PA ct RI; Bir.: 1999. IV. 14., fh, 2000. IV. 20., fh, RGY, 2001. IV. 26., 2001. VI. 26., fh, RI; Nyir.: 2002. IV. 26., fh, RI; Tet.: 2001. IV. 25., fh, RGY; Látrány, Bók-hegy, Duda-tető, 1998. III. 30-31.,
RGY. - Palcarktikus faj, amcly Magyarországon mindenütt elterjedt és nagyon közönséges. Tn.: különfćle kercsztesvirágúak.

Phyllotreta nemorum (Linnacus, 1758) - Lát.: 1998. VI. 28., fh, RI, 2001. IV. 24, RGY. Euroszibériai faj. Magyarországon nagyon gyakori. Első Somogy megyei gyüjtési adatok. Tn.: Brassicaceae.

Phyllotreta undulata (Kutschcra, 1860) - Lát.: 1998. IV. 24., th, RGY; Kol.: 2000. VI. 3., 2001. IV. 26., fh, RI. - Eurázsiai faj. Magyarországon clterjedt és nagyon gyakori. Tn.: Brassicaceae, Reseda lutea.

Phyllotreta ochripes (Curtis, 1837) - Bir.: 2001. IV. 26., fh, RI, 2002. IV. 26., fh, PA - Eurázsiai elterjedésü faj. Magyarországon a vizenyős helycken elterjedt ćs gyakori. Tn.: Alliaria officinalis.

Phyllotreta atra (Fabricius, 1775) - Lát.: 1998. IV. 24., RGY, 1999. VII. 25., fh, RI; Lát1.: 2002. IV. 26., fh, RI; Kol.: 2000. VI. 3., 200I . IV. 25., 2001. VI. 16., fh, RGY, 2001. IV. 26., fh, RI; Bir.: 2001. IV. 26. fh, RI, 2001. VIl. 19., RGY, 2002. IV. 26., fh, PA, 2002. V. 4., autós hálózás, MO. - Euro-turáni faj. Magyarországon nagyon közönséges kártevő. Tn.: Brassicaceae, Reseda sp., Tropaeolum sp.

Phyllotreta diademata Foudras, 1859 - Kol.: 2001. IV. 26., fh, RI, 2002. IV. 26., fh, PA; Bir.: 2001. IV. 26., fh, RI. - Holomediterrán faj. Magyarországon a vizenyös helyeken clterjedt és gyakori. Somogy megyéböl ez az első gyüjtési adat. Tn.: Neslia paniculata és Rorippa fajok.

Phyllotreta aerea (Marsham, 1802) - Kol.: 2001. IV. 26., fh, RI. - Euro-anatóliai faj. Magyarországon elterjedt, de nem gyakori. Ez az clső adata Somogy megyćböl. Tn.: Brassicaceae.

Phyllotreta nigripes (Fabricius, 1775) - Bir.: 2001. X. 5., fh, RI. - Holomcditerrán faj. Magyarországon clterjedt ćs közönsćges. Első Somogy mcgyci gyüjtćsi adat. Tn.: Brassicaceae, Reseda, ćs Tropaeolum fajok.

Phyllotreta procera (Redtenbacher, 1849) - Bir.: 2001. IV. 26., 2001. X. 5., fh, RI. - Holomediterrán faj. Magyarországon elterjedt ćs gyakori. Első Somogy megyei gyüjtćsi adat. Tn.: Brassicaceae, Reseda fajok.

Aphthona nigriscutis Foudras, 1861 - Lát.: 1998. V1. 22., fh, RGY, 1998. VI. 28, fh, RI, 1999. VII. 25., fh, RI, 2002. VI. 30., fh, MO; Látl.: 2001. VII. 10., KE; Kol.: 1999. V. 22 - VI. 24., tcs, RGY, 2000. VI. 3., fh, RI; Bir.: 2000. V. 13., RGY, 2001. VI. 26., fh, Rl. - Pontusi faj. Magyarországon cltcrjedt és közönséges. Tn.: Euphorbia fćlćk.

Aphthona lutescens (Gyllenhal, 1813) - Lát.: 1998. IV. 24., 1998. VI. 22., fh, RGY; Bir.: 2001. IV. 26., fh, Rl. - Euro-turáni cltcrjedésü faj. Magyarországon a vizenyős helycken clterjedt ćs gyakori. Tn.: Lythrum salicariae.

Aphthona venustula (Kutschera, 1861) - Lát.: 2001. IV. 24., fh, RGY; Kol.: 2001. IV. 26., fl, RI; Bir.: 2001. IV. 26., fh, RI, 22. IV. 26., fh, PA - Észak- 
ćs Közćp-curópai faj. Magyarországon a hegy- és dombvidéken elterjedt és gyakori. Tn.: Euphorbia félćk.

Aphthona euphorbiae (Schrank, 1781) - Kol.: 1999. VII. 12., fh, RGY, 2001. IV. 26., fh, RI; Bir.: 2001. IV. 26., fh, RI. - Nyugat-palearktikus faj. Magyarországon mindenfelé elterjedt és közönséges kártevő. Tn.: Linaceae, és Euphorbia fajok.

Aphthona nonstriata (Gocze, 1777) - Lát.: 1998. VI. 22., 1999. IV. 20., 1999. VI. 22., fh, RGY; Bir.: 2000. IV. 20., RGY, 2001. X. 5., fh, PA; Tet.: 2001. IV. 25., RGY - Euroszibériai faj. Magyarországon a vizenyős helyeken elterjedt és gyakori. Tn.: Iris pseudacorus.

Aphthona lacertosa (Rosenhauer, 1847) - Lát:: 1998. VI. 22., 2001. VI. 26., fh, RGY; Kol.: 2000. VI. 4., fh, RGY; Bir.: 2001. IV. 26., 2001. VI. 21., fh, RI. - Közép- és Dél-curópai faj. Magyarországon a füves helyeken elterjedt és gyakori. Somogy megyéböl ezck az clsö gyüjtési adatok. Tn.: Euphorbia félék.

Longitarsus (Longitarsus) pellucidus (Foudras, 1860) - Bir.: 2001. VI. 26., fh, RI. - Turano-mediterrán faj. Magyarországon cltcrjedt ćs közönséges. Tn.: Convolvulus arvensis és Calystegia sepium.
Longitarsus
(Longitarsus)
symphyti

Hcikertinger, 1912 - Bir.: 2001. X. 5., fh, PA. - Európai faj. Magyarországon a vizenyős helyeken elterjedt és gyakori. Elsö Somogy megyci gyüjtési adat. Tn.: Symphytum officinale.

Longitarsus (Longitarsus) rubiginosus (Foudras, 1860) - Lát4.: 2002. IV. 26., fh, RI; Kol.: 2001. X. 5., fh, PA. - Euroszibériai elterjedésü faj. Magyarországon a vizenyős helycken elterjedt, de nem gyakori. Első Somogy megyei gyüjtési adat. Tn.: Calystegia sepium.

Longitarsus (Longitarsus) tabidus (Fabricius, 1775) - Kol.: 2001. X. 5., fh, RI; Bir.: 2002. IV. 26., fh, PA; Nyir.: 2002. IV. 26., PA - Nyugat-palcarktikus faj. Magyarországon közönsćges. Tn.: Verbascum phlomoides ćs más Verbascum ćs Scrophularia fajok.

Longitarsus (Longitarsus) nigrofasciatus (Gocze, 1777) - Bir.: 2001. IV. 26., fh, RI; Nyir.: 2002. IV. 26., fh, PA - Turano-mediterrán faj. Magyarországon sokfelé clöfordul, de nem gyakori. Tn.: Verbascum ćs Scrophularia fajok.

Longitarsus (Longitarsus) melanocephalus (De Geer, 1775) - Kol.: 2000. VI. 3., 2001. X. 5., fh, Rl; Bir.: 1999. IV. 14., 2000. IV. 20., fh, RGY, 2001.IV. 26., fh, RI. - Nyugat-palcarktikus faj. Magyarországon elterjedt ćs közönséges. Tn.: Plantago ćs Silene fajok.

Longitarsus (Longitarsus) pratensis (Panzer, 1794) - Kol.: 2001. X. 5., fh, PA ct RI; Bir.: 1999. IV. 14., fh, RGY, 2001. X. 5., fh, Rl. - Euro-turáni elterjedćsü faj. Magyarországon mindenütt nagyon közönsćges. Tn.: Plantago ćs Chenopodium fajok.

Longitarsus (Longitarsus) atricillus (Linnaeus, 1761) - Lát4.: 2002. IV. 26., fh, RI; Tet.: 2001. IV. 25., fh, RGY - Holomediterrán faj. Magyarországon szórványosan található, nem gyakori. Első Somogy megyei gyüjtési adatai. Tn.: Ranunculus és Mentha fajok.

Longitarsus (Longitarsus) nasturtii (Fabricius, 1792) - Bir.: 2000. IV. 20., fh, RGY, 2001 . IV. 26., fh, RI, 2001. X. 5., fh, PA. - Euroszibériai elterjedésü faj. Magyarországon a vizenyős helyeken közönséges. Tn.: Boraginaceae: Symphytum, Cynoglossum, Echium, Myosotis fajok.

Longitarsus (Longitarsus) holsaticus (Linnaeus, 1758) - Lát.: 1998. IV. 24., fh, RGY. - Euroszibériai faj. Magyarországon elterjedt, de nem gyakori. Első Somogy megyei gyüjtési adat. Tn.: Veronica beccabunga és a Gratiola officinalis.

Longitarsus (Longitarsus) luridus (Scopoli, 1763) - Lát4.: 2002. IV. 26., fh, Rl; Bir.: 2001. IV. 26., 2001. VI. 26., fh, RI. - Nyugat-palearktikus faj. Magyarországon a vizenyős helyeken közönséges. Tn.: Ranunculus, Clematis, Symphytum, Pulmonaria, Satureja, Plantago, Succisa, Mentha fajok.

Longitarsus (Testergus) anchusae (Paykull, 1799) - Lát.: 2001. IV. 26., fh, RI; Kol.: 2001. IV. 26., fh, RI; Bir.: 2001. IV. 26., fh, RI. - Euroszibériai faj. Magyarországon mindenfelé elterjedt és gyakori. Tn.: Boraginaceae.

Altica lythri Aubć, 1843 - Bir.: 2002, IV. 26., kop, PA - Európai faj. Magyarországon fóként a Dunántúlról vannak elterjedési adataink. TN.: Epilobium félćk.

Altica carduorum (Guérin-Méneville, 1858) Lát.: 1998. VIII. 22., fh, RGY; Kol.: 2000. IV. 29., fh, RI. - Adriato-mediterrán faj. Magyarországon a vizenyős helyeken többfelé előfordul, de ritka. Tn.: Carduus, és Cirsium fajok.

Altica pusilla Duftschmid, 1825 - Bir.: 2001. X. 5., fh, RGY - Euroszibériai faj. Magyarországon a vizenyős helyeken található ritka faj. Tn.: Helianthemum guttatum.

Altica cornivorax Král, 1969 - Bir.: 2002. IV. 26., kop, RI - Közép-curópai faj. Magyarországon clterjedt, de nem gyakori. Tn.: Cornus sanguinea

Lythraria salicariae (Paykull, 1800) - Lát: 2001. VI. 26., RGY; Lát5.: 2002. V. 4., fh, MO; Bir.: 1999. VII. 12., fh, RGY; Nyir.: 2002. IV. 26., fh, RI. Euroszibériai faj. Magyarországon a vizenyős helycken elterjedt és gyakori. Tn.: Lysimachia fajok.

Asiorestia ferruginea (Scopoli, 1763) - Lát.: 2001. V. 13., SZD; Kol.: 2000. VI. 3., fh, RI, 2000. VI. 4., 2001. VI. 16., fh, RGY; Bir.: 2001. X. 5., fh, Rl. - Európai faj. Magyarországon elterjedt és közönséges. Tn.: különböző fưfélék, lóhere, bogáncs és az aszat. Asiorestia transversa (Marsham, 1802) - Lát.: 1999. VII. 25., fh, RI; Bir.: 2001. X. 25., fh, RGY. Európai faj. Magyarországon mindenfelé előfordul és gyakori. Tn.: Carduus, Cirsium, ćs Pastinaca fajok.

Hippuriphila modeeri (Linnacus, 1761) - Lát.: 1998. IV. 24., fh, RGY. - Holarktikus faj. Magyarországon a vizenyős helycken gyakori. Tn.: Equisetum fajok. 
Crepidodera aurea (Geoffroy, 1785) - Bir.: 2001. VI. 14., RGY - Palcarktikus faj. Magyarországon a hegy- ás dombvidéken elterjedt és gyakori. Tn.: Populus és Salix fajok.

Crepidodera fulvicornis (Fabricius, 1792) - Kol.: 1999. VII. 12., fh, RGY, 2001. IV. 26., fh, RI; Bir.: 2001. IV. 26., fh, RI; Tet.: 2001. IV. 25., RGY. Palcarktikus clterjedésü faj. Magyarországon mindenfelé elterjedt ćs gyakori. Tn.: Salix és Populus fajok.

Crepidodera aurata (Marsham, 1802) - Lát.: 1998. IV. 24., 2001. IV. 12., 2001. IV. 24., fh, RGY; Lát4.: 2002. IV. 26., fh, Rl; Kol.: 1999. VII. 12., 2000. V. 13., fh, RGY, 2000. IV. 29., 2000. VI. 3., 2001. IV. 26., fh, RI; Bir: 2000. IV. 20., fh, RGY, 2001. IV. 26., 2001. VI. 26., kop, RI, 2001. X. 5., 2002. IV. 26., kop, PA; Tet.: 2001. IV. 25., RGY. Palcarktikus faj. Magyarországon mindenfelé nagyon közönséges. Tn.: Salix és Populus fajok.

Crepidodera plutus (Latreille, 1804) - Bir.: 2001. IV. 26., fh, RI. - Eurázsiai faj. Magyarországon a síkságon és a dombvidéken gyakori. Tn.: Salix és Populus fajok.

Epitrix pubescens (Koch, 1803) - Lát.: 2000. V. 13., KE; Kol.: 2000. VI. 3., fh, RI. - Palcarktikus faj. Magyarországon mindenütt megtalálható és közönséges. Tn.: Solenum dulcamara, S. nigrum, Lycium és Hyosciamus fajok.

Podagrica fuscicornis fuscicornis (Linnacus, 1767) - Bir.: 1999. VII. 12., fh, RGY. - Pontusi faj. Magyarországon mindenütt közönsćges. Tn.: Althea rosea.

Chaetocnema (Tlanoma) chlorophana (Duftschmid, 1825) - Látl.: 2002. IV. 26., fh, Rl; Lát4.: 2002. IV. 26., fh, RI; Lát5.: 2002. V. 4., fh, MO; Kol.: 2001. IV. 26., fh, RI; Bir: 2000. IV. 20., 2001. IV. 25., fh, RGY, 2001. IV. 26, fh, RI. Holomeditcrrán faj. Magyarországon elterjedt ćs nagyon gyakori. Tn.: Calamagrostis epigeios és a Agrostis alba.

Chaetocnema (Tlanoma) concinna (Marsham, 1802) - Lát.: 1999. VII. 25., fh, RI, 2000. V. 13., KE; Kol.: 1999. VII. 12., fh, RGY; Bir.: 2001. VI. 26., 2001. X. 5., fh, RI, 2002. IV. 26., fh, PA. - Eurázsiai faj. Magyarországon mindenütt clöforduló répakártevö. Nagyon közönsćges. Tn.: Rumex, Polygonum, Rheum fajok.

Chaetocnema (Tlanoma) tibialis (Illiger, 1807) Kol.: 2001. IV. 26., fh, RI; Bir.: 2001. X. 5., th, RI. Mcditcrrán faj. Magyarországon mindenfelé clterjedt répakárosító faj. Tn.: Chenopodium album, Atriplex hastata ćs a Salicornia europaea.

Chaetocnema (Tlanoma) conducta (Motschulsky, 1838) - Bir.: 2001. IV. 26., fh, RI. Kclet-mediterrán faj, amelynck cltcrjedése Egyiptomon át cléri az Ethióp Régiót. Magyarországon fölcg a szikes tcrülctcken honos és gyakori. Tn.: Heleocharis palustris és a Juncus fajok.
Chaetocnema (Chaetocnema) aridula (Gyllenhal, 1827) - Bir.: 2001. X. 5., fh, RGY; Tet.: 2001. IV. 25., fh, RGY - Palearktikus elterjedésü faj. Magyarországon mindenütt közönséges. Ezek az első Somogy megyei gyüjtési adatok. Tn.: különbözö füfćlék.

Chaetocnema (Chaetocnema) arenacea (Allard, 1860) - Bir.: 1999. VII. 12., fh, RGY. Holomediterrán faj. Magyarországon a száraz, füves, homokos helyeken nem ritka. Első gyüjtési adat Somogy megyéböl.

Chaetocnema (Chaetocnema) hortensis (Gcoffroy, 1785) - Lát.: 1998. Vl. 22., fh, 2001. IV. 12., RGY, 2001. IV. 29, SZD; Kol.: 2000. IV. 11., RGY, 2001. IV. 26 fh, RI, 2001. X. 5., fh, PA et RI; Bir.: 1999. III. 31., 1999. IV. 14., 1999. VII. 12., fh, RGY, 2001. IV. 26., 2001. X. 5., fh, RI, 2002. IV. 26, fh, PA. - Nyugat-palearktikus faj. Magyarországon mindenfelé közönséges. Tn.: Sesleria coerulea, Arrhenatherum elatius.

Sphaeroderma rubidum (Graëlls, 1858) - Kol.: 2000. V. 13., RGY; Bir.: 2000. VI. 4., fh, RGY. Holomediterrán faj. Magyarországon cltcrjedt ćs gyakori. Első gyüjtési adatok Somogy megyćböl. Tn.: Cisium és Carduus fajok.

Dibolia occultans (Koch, 1803) - Bir.: 1999. VII. 12., fh, RGY, 2001. IV. 26., 2002. IV. 26., fh, RI. Nyugat-palcarktikus faj. Magyarországon a síkságon és a dombvidéken gyakori. Tn.: Mentha aquatica.

Psylliodes (Psylliodes) affinis (Paykull, 1799) Bir.: 2001. IV. 26., fh, RI. - Euroszibériai faj. Magyarországon elterjedt és gyakori. Tn.: Solanaceae.

Psylliodes (Psylliodes) attenuata (Koch, 1803) Lát 1.: 2002. IV. 26., fh, RI; Lát4.: 2002. IV. 26., fh, RI; Bir.: 2000. IV. 20., RGY, 2001. IV. 26., fh, RI, 2002. IV. 26., fh, PA; Tet.: 2001. IV. 25., fh, RGY Palcarktikus faj. Magyarországon elterjedt ćs közönséges kártevő. Első Somogy megyei gyüjtési adatok. Tn.: komló és a kender.

Psylliodes (Psylliodes) chrysocephala (Linnacus, 1758) - Látl .: 2002. IV. 26., fh, RI; Lát4.: 2002. IV. 26., fh, RI; Kol.: 2001. X. 5., fh, PA et RI; Bir.: 2001. IV. 26., fh, RI, 2001. X. 5., fh, PA et RI, 2002. IV. 26., fh, PA. - Euroszibériai faj. Magyarországon közönsćges. Tn.: Brassica oleracea és a Brassica napus.

Psylliodes (Psylliodes) napi napi (Fabricius, 1792) - Kol.: 2000. VI. 3., fh, RI; Bir.: 2001. X. 5., fh, RI - Euro-afrikai faj. Magyarországon a rétcken, vizenyös helycken fordul elö a hegy és dombvidéken, de ritka. Első Somogy megyci gyüjtćsi adat. Tn.: Alliaria officinalis, Nasturtium ćs Cardamine fajok.

Psylliodes (Psylliodes) brisouti Bcdel, 1898 . Bir.: 2001. IV. 26., fh, RI. - Európai hagyvidćki faj. Magyarországon szórványosan, de nagyon ritka. Somogy megyéböl $\mathrm{cz}$ az első adat.

Psylliodes (Psylliodes) chalcomera (Illiger, 1807) - Bir.: 2002. IV. 26, fh, PA - Nyugat-paleark- 
tikus faj. Magyarországon elterjedt és gyakori. Első Somogy megyei gyűjtési adat. Tn.: Carduus és Cirsium fajok.

\section{Hispinae Gyllenhal, 1813}

Hispella atra (Linnaeus, 1767) - Lát.: 1998. VI. 22., 2001. IV. 12., fh, RGY, 2001. V. 23., SZD; Lát4.: 2002. IV. 26, fh, Rl; Kol:: 2000. IV. 11., RGY, 2001. IV. 26., fh, RI; Bir.: 1999. VII. 12., 2000. V. 13., fh, RGY, 2001. IV. 26., 2001. VI. 26., 2001. X. 5., fh, RI, 2002. IV. 26., fh, PA; Nyir.: 2002. IV. 26., fh, RI. Palcarktikus faj. Magyarországon mindenütt közönséges. Tn.: Poa compressa, Agropyron repens.

\section{Cassidinae Gyllenhal, 1813}

Cassida (Lordiconia) canaliculata Laicharting, 1781 - Lát.: 1998. VI. 27., th, RGY. - Europai faj. Magyarországon a hegy- és dombvidéken elterjedt, de nem gyakori. Somogy megyćból ez az első gyüjtćsi adat. Tn.: Salvia pratensis.

Cassida (Cassida) nebulosa Linnacus, 1758. Lát:: 2001. IV. 24., RGY, 2001. VII. 10., KE; Lát5.: 2001. VII. 5., fh, MO; Bir.: 2001. IV. 26, fh, RI, 2001. IV. 25., 2001. VII. 19, 2001. X. 5., RGY, 2002. IV. 26., fh, PA; Nyir.: 2002. IV. 26., fh, RI. - Palcarktikus clterjedésü faj. Magyarországon mindenütt közönséges. Tn.: Chenopodium album és a Atriplex hastata.

Cassida (Cassida) atrata Fabricius, 1787 - Kol.: 2000. IV. 11., fh, RGY; 2001. VI. 14., fh, RGY. Ponto-mediterrán faj. Magyarországon elterjedt, do ritka. Első Somogy megyci gyüjtési adat. Tn.: Salvia pratensis és a Salvia glutinosa.

Cassida (Cassida) vibex Linnaeus, 1767 - Lát.: 1998. VI. 27., 2001. VII. 3., RGY, 1998. VI. 28., RI, 2000. V. 13., 2001. VII. 10., KE; Lát4.: 2001. VII. 3. KE, 2002. IV. 26., fh, RI; Kol.: 2001. X. 5., PA; Bir.: 2000. IV. 29., 2000. V. 13., 2001. X. 5., RGY; Nyir.: 2002. IV. 26., fh, Rl. - Palcarktikus faj. Magyarországon közönsćges. Tn.: Cirsium arvense, Cirsium palustre, Chrysanthemum vulgare.

Cassida (Cassida) pannonica Suffrian, 1844. Lát 1.: 2001. VII. 5., fh, MO; Kol.: 2002. IV. 26., th, PA. - Turano-mediterrán elterjedésü faj. Magyarországon a homokos vidéken elterjedt és gyakori. Tn.: Centaurea fajok.

Cassida (Cassida) rubiginosa O. F. Müller, 1776 - Lát.: 2001. IV. 24., RGY; Látl.: 2002. IV. 26., fh, RI; Bir.: 2000. VI. 4., 2000. V. 13., RGY, 2001. VI. 26., fh, RI. - Holarktikus faj. Magyarországon közönséges. Tn.: Carduus és Cirsium fajok, valamint az
Onopordum acanthium, Arctium lappa, Sonchus oleraceus, Chrysanthemum vulgare.

Cassida (Cassida) aurora Weise, 1907 - Lát.: 2001. IV. 24., RGY - Közép-európai faj. Magyarországon csak néhány helyröl, főként a Dunántúlról ismert. Tn.: Achillea millefolium.

Cassida (Cassida) denticollis Suffrian, 1844. Lát.: 2001. IV. 12, RGY; Lát5.: 2002. V. 4., fh, MO; Kol.: 2000. IV. 29., 2001. IV. 26, fh, RI, 2000. VI. 3., RGY; Bir.: 1999. Ill. 31., 1999. IV. 14., fh, RGY, 2001. IV. 26, fh, RI. - Euroszibériai faj. Magyarországon elterjedt és közönséges. Tn.: Chrysanthemum vulgare és az Achillea millefolium.

Cassida (Cassida) sanguinolenta O. F. Müller, 1776 - Lát.: 1998. VI. 22., 1998. VIII. 22., fh, RGY; Bir.: 2000. V. 13., RGY. - Euroszibériai faj. Magyarországon elterjedt ćs gyakori. Tn.: Achillea millefolium.

Cassida (Cassida) prasina Illiger, 1798 - Lát.: 2000. V. 13., KE, 2001. VI. 16., RGY, 2002. VI. 30., fh, MO; Lát5.: 2002. V. 4., fh, MO; Bir.: 2001. VI. 26., fh, RI, 2002. IV. 26., fh, PA. - Euroszibériai faj. Magyarországon elterjedt és gyakori. Tn.: Achillea, Chrysanthemum, Matricaria és Anthemis fajok.

Cassida (Pseudocassida) murraea Linnaeus, 1767 - Lát4.: 2001. VII. 3., KE; Lát6.: 2001. VII. 3., KE. - Euroszibériai faj. Magyarországon föleg a vizenyös helyeken elterjedt, de nem gyakori. Elsö Somogy megyei gyüjtési adatai. Tn.: Pulicaria dysenterica, Inula salicina, Inula britannica, Verbascum thapsus és a Mentha félék.

Cassida (Mionycha) subreticulata Suffrian, 1844 - Lát.: 1998. VIII. 20., fh, RGY; Bir.: 2001. IV. 26. fh, RI; Kol.: 2002. IV. 26., fh, PA; Nyir.: 2002. IV. 26., fh, PA. - Eurázsiai faj. Magyarországon a homokos helycken található, de nem gyakori. Első Somogy megyci gyüjtési adat. Tn.: Saponaria officinalis és az Antennaria dioica.

Cassida (Mionycha) margaritacea Schaller, 1783 - Lát.: 1998. Vl. 28., 1999. VII. 25., fh, RI, 1998. VIII. 22., 1999. III. 31., 1999. VIII. 22., 2001. VI. 16., fh, RGY, 2000. V. 13., 2001. IV. 13., KE; Bir.: 1999. III. 31., 1999. IV. 14., 2000. V. 13., fh, RGY. - Pontusi faj. Magyarországon a síkságon és dombvidéken a legelökön és réteken elterjedt és gyakori. Tn.: Saponaria officinalis, Spergula arvensis, Silene cucubalus, Helichrysum arenarium, Anaphalis margaritacea, Thymus serpyllum és a Centaurea fajok. 


\section{Értékelés}

1998 és 2002 évek között a látrányi pusztán gyüjtött levélbogarak családjából (Chrysomelidae) 11 alcsalád, 44 nemének 144 faja volt kimutatható. Ebböl a 144 fajból eddig semmilyen publikációban nem szerepelt 38 faj, így ezek Somogy megyére nézve új elterjedési adatot jelentenek. VIG (2001) adatai szerint 241 somogyi levélbogarat ismertünk. Ezzel a 38 fajjal az ismert Somogy megyei levélbogarak száma 279-re emelkedett.

1. táblázat: A Kárpát-medencében, Magyarországon, Magyarország egyes tájegységein, illetve védett területein kimutatott levélbogár fajok száma, és azok százalékos megoszlása a magyar faunához viszonyítva

\begin{tabular}{|l|c|c|}
\hline Vizsgált terület & Kimutatott fajok száma & A magyar fauna \%-ban \\
\hline Kárpát-medence & 669 & - \\
\hline Magyarország & 535 & $100 \%$ \\
\hline Bátorliget TT (1953) & 151 & $28,20 \%$ \\
\hline Bátorliget TT (1990) & 190 & $35,50 \%$ \\
\hline Hortobágyi NP (1981) & 146 & $27,20 \%$ \\
\hline Kiskunsági NP (1987) & 246 & $45,90 \%$ \\
\hline Bükki NP (1996) & 278 & $51,90 \%$ \\
\hline Aggteleki NP (1999) & 231 & $43,10 \%$ \\
\hline Örségi TK (1996) & 223 & $41,60 \%$ \\
\hline Duna-Dráva NP (1998) & 157 & $29,30 \%$ \\
\hline Ny-Magyarországi peremvidék ('96) & 352 & $65,70 \%$ \\
\hline Bakony hegység (1992) & 384 & $71,70 \%$ \\
\hline Somogy megye (2001) & 241 & $45 \%$ \\
\hline Látrányi-puszta TT (2002) & 144 & $26,90 \%$ \\
\hline Somogy megye (2002) & 279 & $52,10 \%$ \\
\hline
\end{tabular}

A fenti táblázatot elemezve kitünik, hogy a látrányi pusztán kimutatott levélbogár fajok száma közel azonos az igen nagy területü Hortobágyi NP-ból kimutatott fajszámmal, és nem sokkal marad el a Duna-Dráva NP-ból leírt fajok számától. Figyelemre méltó a Somogy megyéből kimutatott levélbogár fajok számának növekedése, amely az eddigi kutatások alapján már meghaladja a magyarországi fajok $50 \%$-át.

Az eddigi látrány pusztai gyüjtésekből a magyar faunára nézve új faj nem került elő. De begyüjtésre került néhány ritka vagy kevés magyarországi lelőhelyről ismert faj. Ezek közül említésre méltók az alábbiak:

Smaragdina flavicollis (Charpentier, 1825). Ez a faj előfordul Algériától Dél- és Közép-Európán, a Balkán-félszigeten át Kis-Ázsiáig. Faunaterületünkön általában a hegyvidéken található ritkább faj. Magyarországon több helyről előkerült, a Dunántúlról az Örségböl, a Szigetközből, a Bakony hegységből, az Északi-Középhegységből, de a Kárpát-medencében a leggyakoribb a Kárpátok hegyeiben a Felvidéken és Erdélyben. Tápnövénye az irodalmi adatok szerint az enyves éger (Alnus glutinosa).

Pachybrachis sinuatus Mulsant et Rey, 1859 (= haliciensis Suffr.). Közép-európai hegyvidéki faj, amely a hegyi patakok és folyók mentén a csermely cipruson (Myricaria germanica) és föleg a füzféléken él. KASZAB (1962) szerint a nagy folyók mentẹn (Győr, Szeged) az árvízek révén került az országba, és itt megtelepedett. Somogy megyéböl a 
Dráva-partról több lelöhelyről is ismert. Látrányi gyüjtéseink azért érdekesek, mert itt nincsenek nagyobb folyók.

Cryptocephalus macellus (Suffrian, 1860). Ez a közép- és dél-európai faj, amely Bulgárián át Kisázsiáig fordul elő, Magyarországon a síkságon és a dombvidéken szórványosan található ritka faj. KASZAB (1962) három alföldi lelőhelyről említi (Budapest, Alsódabas, Szeged). Somogy megyéből a látrányi gyüjtést megelőzően nem került elő, így a látrányi gyüjtési adat nagyon értékes a faj elterjedése szempontjából.

Cryptocephalus gridellii Burlini, 1956. Ez az adriato-mediterrán elterjedésü faj előfordul Olaszországban, Dalmáciában, Horvátországban és Dél-Magyarországon. Hazánkban nagyon ritka. KASZAB (1962) három magyarországi lelőhelyét említi (Kalocsa, Pécs, Jászó). Azóta elökerült két balatonfelvidéki lelöhelyről is (Balatonudvari, Barnag). Somogyból nem volt eddig ismert, ezért a látránypusztai gyüjtési adata nagyon értékes.

Cryptocephalus parvulus O.F. Müller, 1776. Euroszibériai elterjedésü faj, melynek áreája Japánig terjed. Faunaterületünkön a síkság vizenyős területein él, de ritka. A Dunántúlon gyüjtötték a Bakonyban, az Őrségben és a Villányi-hegységben. Somogy megyéből az első gyüjtési adata a Látrányi puszta.

Galeruca dahli (Joannis, 1865). Dél- és közép-európai faj, amelynek elterjedése Franciaországtól és Itáliától a Krim-félszigeten át a Kaukázusig ér. Hazánkban mindenütt ritka. KASZAB (1962) szerint a legtöbb lelöhelyadata a Dunántúlról származik, de gyüjtötték már Szabolcs megyében (Kömörőd) is. Látrányi gyüjtési adata igen értékes a faj hazai elterjedésének szempontjából.

Luperus longicornis (Fabricius, 1781). Eurázsiai faj, melynek elterjedése Irországtól délen Mezopotámiáig, ill. Közép-Ázsián át Kináig és Japánig ér. Faunaterületünkön a hegyvidéken elterjedt, föként a Kárpátokban található, Magyarországon ritka. Dunántúli elterjedési adataink vannak (Mosonmagyaróvár, Örség, Alpokalja). Somogy megyei gyüjtési adata jelentős a faj elterjedésének ismeretéhez.

Phyllotreta aerea (Marsham, 1802). Euro-anatóliai faj, amelynek elterjedése Irországtól Dél- és Közép-Európán át (kivéve az Ibériai-félszigetet) Anatóliáig terjed. Magyarországon az Alföldön és az alacsonyabb hegy- és dombvidéken elterjedt, de nem gyakori. Dunántúlon a Bakonyból ismerjük. A látránypusztai Kolláti-legelön gyüjtött példányai a faj első somogyi gyüjtési adatai.

Altica lythri Aubé, 1843. Ennek az európai fajnak magyarországi elterjedésére KASZAB (1962) négy adatot közöl (Mohács, Celldömölk, Magyaróvár és Budapest környéke). Azóta a Bakony hegységből több helyről is elökerült, de a Fertő-Hansági Nemzeti Parkban, Lébényben, a Duna-Dráva Nemzeti Parkban és az Alpokalján is gyüjtötték. A látrányi gyüjtése a faj elterjedésének fontos adata.

Altica pusilla Duftschmid, 1825. Ez az euroszibériai elterjedésü faj Magyarországon főleg a síkság vizenyős rétjein, lápjain található, de ritka. KASZAB (1962) öt lelőhelyét emliti, köztük egy somogyi előfordulását is (Siófok). Azóta nagyobb számban az Örségi TK több lelőhelyéről előkerült, de gyüjtötték a Bakony hegységben is. Látrányi gyüjtési adata jól jellemzi a terület nedves, lápos foltjait.

Psylliodes brisouti Bedel, 1898. Európai hegy- és dombvidéki faj. KASZAB (1962) három lelöhelyét említi (Sopron, Bükk hg., Mátra-hegység). A Villányi-hegység kutatása során ugyancsak elökerült. A látrányi Birkás-legelőn gyüjtött példányok a faj első Somogy megyei gyüjtési adatát jelentik, de értékes adat ez a faj hazai elterjedéséhez is.

Cassida aurora Weise, 1907. Ezt a kis elterjedésü Közép-európai fajt KASZAB (1962) mindössze két dunántúli (Dombovár, Siófok) és egy tiszántúli (Békéscsaba) lelőhelyről említi. Azóta már gyüjtötték a Villányi-hegységben és az Örségben is egy-egy lelöhelyröl, de elökerült Bereg megyéből (Kaszonyi-hegy) is. Látrányi gyüjtési adata fontos a faj elterjedésének ismeretéhez. 


\section{Köszönetnyilvánítás}

A szerző e helyen szeretne köszönetet mondani dr. Ábrahám Leventének, a Somogy Megyei Múzeum Természettudományi Osztálya vezetőjének, hogy lehetővé tette a Látrányi puszta kutatásában való részvételemet. Köszönet illeti dr. Kondorosy Elődöt, dr. Merkl Ottót, Podlussány Attilát, Rozner Györgyöt és Szalóki Dezsőt, hogy az általuk gyüjtött levélbogarakat feldolgozásra a rendelkezésemre bocsátották.

\section{Irodalom}

Gruev B., MerkL O. 1992: To the geographic distribution of the Longitarsus pratensis-group (Colcoptera, Chrysomclidac: Alticinac). - Folia ent. hung. 52: 15-20.

KASZAB Z. 1962: Lcvélbogarak - Chrysomclidac. - In: Magyarország állatvilága, IX: 6 (Fauna Hungariac 63), Akadémiai Kiadó, Budapest pp.1-416

Kıppenberg H., Dörbel M. 1994: 88. Familic: Chrysomclidac. - In.: Lohse, G.A. \& Lucht, W.H. (szerk.): Die Käfer Mittcleuropas: 3. Supplementband mit Katalogteil, Goccke \& Evers, Krefeld 17-142. pp.

KRÁL J. 1969: Zur Kenntis der paläarktischen Altica-Arten V. (Coleoptera, Phytophaga, Alticidac) - Entomol. Blätter, Krefeld 65(2): 72-85.

KuthY D. 1896: Ordo Coleoptera. - In.: A Magyar Birodalom Állatvilága - Fauna Regni Hungariac, K.M. Termtud. Társulat, Budapest pp. 1-213.

LeONARdi C. 1971: Considerazioni sulle Psylliodes del gruppo napi e descrizione di una nuova specie. (Colcoptera, Chrysomclidae). - Atti Soc. It. Nat. e Museo Civ. St. Nat. Milano - 112(4): 458-533.

Mohr K. H. 1966: 88. Familic: Chrysomelidac - In: Lohse, G.A., Harde, K.W. \& Freude, H. (szerk.): Die Käfer Mittelcuropas, Band 9, Goecke \& Evers, Krefeld pp. 95-299.

ROzNER I. 1983: Adatok a Bakony-hegység levélbogár-faunájához I. (1968-1982), (Colcoptera: Chrysomelidac) - Folia Mus. Hist.-Nat. Bakonyiensis 2: 89-104.

RozNer 1. 1986: Adatok a Bakony-hegység levélbogár-faunájához 11. (1968-1984), (Coleoptera: Chrysomelidae) - Folia Mus. Hist.-Nat. Bakonyiensis 5.: 39-56.

ROZNER 1. 1988: Adatok a Bakony-hegység levélbogảr-faunájához 1ll. (1968-1984), (Coleoptera: Chrysomclidae) - Folia Mus. Hist.-Nat. Bakonyiensis 7: 49-70.

RozNer I. 1988: Adatok a Bakony-hegysćg levélbogár-faunájához IV. (1968-1988), (Colcoptcra: Chrysomelidac) - Folia Mus. Hist.-Nat. Bakonyiensis 9: 35-70.

ROZNER 1. 1992: A Bakony-hegysćg levélbogarainak (Colcoptera: Chrysomelidac) állatföldrajzi vizsgálata. Folia Musci Hist.-Nat. Bakonyiensis 11: 151-165.

ROZNER 1. 1996: An updated list of the Chrysomelidac of Hungary and the adjoining parts of the Carpathian Basin (Colcoptera) - Fol. Entom. Hung., Budapest, LVIl, pp. 243-260.

Тóтн L. 1979: A Bakony hegysćg levélbogár faunájának alapvetése - Veszprém Megyei Múz. Közlem. 14.: 115-136.

VIG K. 1996: A Nyugat-magyarországi-percmvidék levélbogár faunája (Coleoptera: Shrysomelidae sensu lato). - Praenorica, Folia hist.-nat, 3: 1-178.

VIG K. 1998: A Duna-Dráva Nemzeti Park levélbogár faunája (Coleoptera: Chrysomelidae sensu lato) - In: Uherkovich Ákos (szerk.): A Dráva mente állatvilága, II., Dunántúli Dolgozatok Tcrmészettudományi Sorozat 9: 249-268.

VIG K. 2000: A Villányi-hegysćg levćlbogár faunája (Colcoptera, Chrysomelidac sensu lato) - In: Uherkovich Ákos (szerk): A Villányi-hegysćg botanikai és zoológiai alapfelmérése, Dunántúli Dolgozatok Természettudományi Sorozat 10: 229-248.

VIG K. 2001: Somogy megye lcvélbogár- és zsizsikfaunája (Colcoptera: Chrysomelidac, Bruchiidae) - In: Ábrahám L. (szerk.): Somogy fauna katalógusa, Natura Somogyensis, 1: 221-236

VIG K., ROZNER 1. 1996: Leaf beetlc fauna of Örség (Colcoptera: Chrysomclidac sensu lato). - In: Vig K. (szerk.): Az Örsćgi Tájvćdelmi Körzet természeti képc II. , Savaria, A Vas Megyei Múzeumok Értesitöje, 23/2: 163-202.

WARChalowskı A. 1994: Chrysomclidae (Ins., Col.) - In Fauna Poloniae, (Chrysomclina, Gonioctenia, Phratorina, Entomoscelina, Galerucinac), Warszawa 16(4): 1-302.

Warchalowski A. 1995: Chrysomclidae (Ins., Col.) - In Fauna Poloniac, (Halticinac: Phyllotreta, Aphthona, Longitarsus), Warszawa 17(5): 1-360. 


\section{The leaf beetle fauna of the Látrányi Puszta Nature Conservation Area (Coleoptera: Chrysomelidae)}

\section{ISTVÁN ROZNER}

Látrányi Puszta Nature Conservation Area was established on 223 hectares in 1992. The area is covered by sandy grassland and wet meadows. The research on leaf beetles (Coleoptera, Chrysomelidae) was carried out between 1998 and 2002. In the course of research, 11 leaf beetle subfamilies, 44 genera and 144 species were recorded in the area. The species represent $27 \%$ of the Hungarian leaf beetle fauna. The occurrence of 38 species has not been recorded in Somogy County so far. Some of the rare species (known to occur on a very few sampling sites in Hungary) were collected, such as: Smaragdina flavicollis (Charpentier, 1825), Pachybrachis sinuatus Mulsant et Rey, 1859, Cryptocephalus macellus Suffrian, 1860, Cryptocephalus gridellii Burlini, 1956, Cryptocephalus parvulus O. F. Müller, 1776, Galeruca dahli (Joannis, 1865), Luperus longicornis (Fabricius, 1781), Phyllotreta aerea (Marsham, 1802), Altica lythri Aubé, 1843, Altica pusilla Duftschmid, 1825, Psylliodes brisouti Bedel, 1898, Cassida aurora Weise, 1907. 